Insight, part of a Special Feature on Do we need new management paradigms to achieve sustainability in tropical forests?

\title{
Sustainable Forest Management in Cameroon Needs More than Approved Forest Management Plans
}

\author{
$\underline{\text { Paolo Omar Cerutti }}^{1}, \underline{\text { Robert Nasi }}^{1}$, and $\underline{\text { Luca Tacconi }}^{2}$
}

\begin{abstract}
One of the main objectives of the 1994 Cameroonian forestry law is to improve the management of production forests by including minimum safeguards for sustainability into compulsory forest management plans. As of 2007, about 3.5 million hectares $(60 \%)$ of the productive forests are harvested following the prescriptions of 49 approved management plans. The development and implementation of these forest management plans has been interpreted by several international organizations as long awaited evidence that sustainable management is applied to production forests in Cameroon. Recent reviews of some plans have concluded, however, that their quality was inadequate. This paper aims at taking these few analyses further by assessing the actual impacts that approved management plans have had on sustainability and harvesting of commercial species. We carry out an assessment of the legal framework, highlighting a fundamental flaw, and a thorough comparison between data from approved management plans and timber production data. Contrary to the principles adhered to by the 1994 law, we find that the government has not yet succeeded in implementing effective minimum sustainability safeguards and that, in 2006, $68 \%$ of the timber production was still carried out as though no improved management rules were in place. The existence of a number of approved management plans cannot be used a proxy for proof of improved forest management.
\end{abstract}

Key Words: Cameroon; certification; law enforcement; sustainable forest management

\section{INTRODUCTION}

For the last 15 years, Cameroon has been at the forefront of the Congo Basin countries for its innovative forestry legal framework. A Ministry of Environment and Forests (MINEF) was created in 1992 (now the Ministry of Forests and Fauna (MINFOF), hereafter referred to as the ministry) and a forest policy document produced in 1993. In 1994, forest law $\mathrm{N}^{\circ}$ 94-01 regulating forests, wildlife, and fisheries (Republic of Cameroon 1994) was voted and then implemented through a 1995 decree (Republic of Cameroon 1995). The objective was to guarantee the sustainable management of forest resources through both conservation and production (art. 1). The law mandates that logging companies must prepare detailed forest management plans (FMPs) to ensure the ecological, economic, and socially sustainable management of their forests.
As of 2007, all available 101 forest management units (FMU) had been granted by the ministry, and 49 of these (about 3.5 million ha) are managed according to approved management plans (MINFOF 2007). Several international organizations point to the efforts made by the Cameroonian government toward improved sustainability (e.g., Inter-African Forest Industries Association (IFIA) 2006; International Tropical Timber Organisation (ITTO) 2006), and see the growing number of approved FMPs as an indicator of improved sustainable management (Commission des Forêts d'Afrique Centrale (COMIFAC) 2004, Congo Basin Forests Partnership (CBFP) 2006, German Development Cooperation (GTZ) and MINFOF 2006).

So far, no comparison between prescriptions in approved management plans and actual management practices in logging concessions in Cameroon has 
been attempted. The objective of this paper is to assess the impacts that approved plans have on sustainability and timber production practices. This is a relevant issue to consider because:

- management plans can be revised 5 years after approval to be better adapted to actual forest conditions. This 5-year timeline will soon be reached in many plans, but the ministry has not yet started to critically compare estimated annual allowable cuts (AACs) from management plans and the parameters used to calculate these AACs with actual production data. Without this, it might prove a difficult task for the ministry to detect inappropriate harvesting and request companies to revise their management plans.

- on November 2007, the government of Cameroon, as proof of its political commitment to sustainable management, started negotiating a Voluntary Partnership Agreement (VPA) with the European Union (EU). This VPA aims at "contributing to the commitments of timber-producing countries to promote sustainable forest management" (European Commission 2007:1). It remains to be seen whether the high-level political commitment translates into any actual implementation on the ground through FMPs. If not, the VPA's legal requirement to have an approved management plan in order to obtain a legality certificate could be easily fulfilled although not achieving real progress toward sustainable forest management.

We analyze the regulations applying to the management of Cameroonian forests. We focus on a fundamental flaw of the legal framework that allows logging companies to ignore some of the most harvested species in their FMPs. By comparing the most recent production data with technical prescriptions of approved management plans for 38 FMU, we illustrate how legal weaknesses, coupled with feeble controls by the ministry, result in a large part of the annual production being realized as if no management rules were applied. The final section analyzes how the ongoing certification process demonstrates that the legal framework allows inappropriate harvesting, but also could be used as evidence by the ministry to help correct the legal flaws and improve forest management. For that to happen, however, the ministry must fulfill its role concerning management issues and become an involved and active stakeholder.

\section{FOREST MANAGEMENT IN CAMEROON}

Cameroonian forests have a long history of regulatory and institutional settings. During the colonial period, Germany, the United Kingdom, and France had administrative units in place to regulate the forestry sector (Hédin 1930, Letouzey 1957), and after independence, new forest laws were adopted by the Republic of Cameroon in 1974 and 1981. It was not until 1994 that, with the adoption of a new forest law, a comprehensive national forest policy framework was laid down directly linking the concepts of sustainable forest management with the preparation of FMPs for all productive forests.

According to the most recent assessment made by the ministry of forests in collaboration with the FAO, Cameroonian forests cover a surface of about 21.2 million hectares, i.e., $45 \%$ of the national territory (MINFOF and FAO 2005). The estimated deforestation rate varies according to sources and methods of estimation (e.g., see Wunder 2003 for a recent comparison of available sources). MINFOF and FAO (2005) indicate an annual loss of forests of about 100000 ha between 1975 and 2004, or $0.48 \%$ per year. Half of the lost forested surfaces were degraded into "other wooded lands," whereas half were transformed into "other lands,", mainly used for agriculture (MINFOF and FAO 2005).

The 1994 law divides Cameroonian forests into two domains (art. 20, Republic of Cameroon 1994): the permanent forest domain-land permanently allocated to forests and/or wildlife habitats, and the non-permanent forest domain - forested lands that can potentially be allocated to other land uses. Permanent forests must (a) cover at least $30 \%$ of the national territory, (b) be representative of the national biodiversity and, in order to guarantee their sustainable use, (c) be managed according to a management plan approved by the ministry. Protected areas, such as national parks, are part of the permanent forest domain and need to be managed accordingly. However, the objectives of their FMPs are different from those required for production forests and will not be considered in this paper. Our analysis will not consider other requirements that logging companies must fulfil, such as social demands, land tenure, non-timber forest products, and wildlife protection. 
Forest management units are part of the permanent forest domain and they are publicly auctioned. After allocation, the winning company can immediately start harvesting but it has an obligation to prepare a FMP within a maximum period of 3 years. The plan must ensure the sustained production of forest goods and services, without (a) endangering the intrinsic values and the future productivity of the permanent forest, and (b) creating unwanted effects on the physical and social environment (art. 23, Republic of Cameroon 1994).

The management plan is a document in which the potentialities of the resource are evaluated, the trade-offs among the ecological, economic, and social aspects of management are assessed, and balanced solutions are proposed. The 1994 law states that the development of management plans is a prerogative of the State. However, lack of human and financial resources led the State to delegate this task to logging companies, with the logical consequence that economic aspects generally received more attention than ecological or social ones.

Balanced outcomes are sought and negotiated in the management plan through the values assigned to a handful of fundamental silvicultural parameters. The most important of these parameters are the length of the harvesting cycle inside the FMU (rotation period), the selection of a list of key species on which yield calculation will be based, and the minimum diameter (minimum cutting diameter, MCD) at which these species can be cut. These parameters directly influence the AAC, which can correspond either to the maximum theoretical volume of timber or the maximum area that can be harvested annually.

The rotation period represents the lapse of time between two logging operations at the same place inside the FMU and the period needed for harvesting operations to cover the whole FMU. The law fixes a minimum rotation period of 30 years, but companies can increase it for improved sustainability. The literature lists several parameters, biological as well as socioeconomic, that influence the length of the rotation period (Durrieu de Madron et al. 1998, Fargeot et al. 2004, Luckert and Williamson 2005). However, to date, all management plans have been based on the legal minimal prescription of 30 years, as if the rotation period was a fixed parameter. This is mainly because a FMU is granted for a 15-year period that is only renewable once. Therefore, logging companies cannot be expected to base their management decisions on longer periods, incurring the risk of leaving valuable trees standing for a future harvest that could be granted to another company.

The list of key species selected by the logging companies for inclusion in the management plan is another important parameter in the context of highly selective logging occurring in Cameroon (less than one tree/ha in 2006). The management inventory considers all commercial species as well as a host of species with specific technological qualities, sufficiently abundant and homogeneously distributed inside the FMU (Fargeot et al. 2004). Therefore, it is possible for the company to design a balanced list of key species including the ones actually harvested and the most promising candidates for the future. In practice, most companies already have a broad idea of the few key species that could guarantee the economic viability of the FMU even before bidding for it. Thus, companies will tend to base their management strategy on those species even after carrying out the mandated management inventory. However, management decisions solely based on companies' economic concerns might not be in line with long-term considerations and sustainable use of the resource. The role of the ministry is of the utmost importance. First, it must assess all management inventory reports and lists of selected species, to check that all valuable species are part of management decisions. Second, it must create conditions favoring harvesting and marketing of lesser known species (Fargeot et al. 2004).

In practice, given the still limited knowledge about the biology of many tropical timber species, notably about regeneration processes (Repetto 1988, Fargeot et al. 2004, Karsenty and Gourlet-Fleury 2006), the specialized literature suggests being careful in deciding management parameters to ensure species recovery (Durrieu de Madron et al. 1998, Forni and Mbarga 1998, Ntep 2000, Jonkers and Foahom 2004). In its regulations, the ministry tries to balance available knowledge (MINEF 1998a, b), diminishing biological diversity risks and economic concerns. It suggests, therefore, a minimum reconstitution rate of $50 \%$ of the initial stock, in terms of number of trees of any given species. Logging companies agree to this safeguard and, in the words of the first Forest Stewardhip Council (FSC)-certified company in Cameroon, "the reconstitution rate of $50 \%$ is accepted to guarantee the perpetuation of the species" (Wijma Douala S.A.R.L. 2004:58). As the rotation period is fixed, for all practical purposes, the rate of 
reconstitution is only dependent on population structure (a given condition) and on MCDs. Once key species are selected, their MCD must be decided. Originally, the MCD was decided on the basis of the industry's requirements without real concern about ecological processes. Nowadays, MCDs are somewhat based on biological considerations like the minimum diameter at which effective fruiting occurs or the diameter structure of the population. The MCD is mainly chosen to ensure that there will still be a significant number of harvestable individuals left for the next rotation period, i.e., $50 \%$ of the pre-logging situation.

Notwithstanding the apparent wide acceptance of the above-mentioned precautionary approaches, the regulations adopted for the preparation of management plans have not been able to achieve their implementation. As we shall demonstrate in the following sections, the legal framework remains flawed. It has negative impacts on the effectiveness of management plans to ensure the sustainable harvest of some of the most valuable species.

\section{THE FLAWED LEGAL FRAMEWORK}

The forest law mandates that FMUs be managed according to approved management plans. The 1995 implementation decree, in turn, mandates that for each FMU an AAC must be calculated and included in the plan (Republic of Cameroon 1995). The AAC must be estimated by companies on the basis of the average volume per hectare of some key species designated as "commonly traded species" ("essences de commerce courant") (art. 62/1). The list of these managed species is one of the important parameters of the management plan.

The emphasis given by the 1995 decree to the AAC (calculated using the "commonly traded species") deserves particular attention given the historic pattern of timber harvesting in Cameroon, which has always focused on a narrow range of high-value species (Schanz 1914, Meniaud 1948, MINEF 2004). The calculated AAC of a given FMU must be based on all the actually logged species inside one FMU to be meaningfully used, both by the company and by the ministry, for management and planning purposes.

However, the 1995 decree did not provide sufficient details on the procedures to be followed by logging companies in preparing their management plans, and subsequent specific regulations had to be prepared in 1998 and again in 2001, when decree No 0222 was adopted (MINEF 1998a, b, 2001). From 2001 onward, logging companies have based the preparation of their management plans on decree 0222, and as of September 2007, the ministry had approved 49 management plans (MINFOF 2007).

Specifically, decree $\mathrm{N}^{\circ} 0222$ asks that the company "choose the managed species among those provided in the list of main species," the latter defined as the about 60 most harvested species nationwide, and that these "managed species must be at least 20 and represent at least $75 \%$ of the total harvestable volume of the FMU" (art. 6, MINEF 2001). However, the decree does not ask companies to select their key "managed species" among the species they harvest the most inside the concerned FMU.

Decree $\mathrm{N}^{\circ} 0222$ provides the government with all the necessary options to force companies to take more sustainable decisions. In particular, the decree lists a set of criteria for the ministry to apply before approving management plans: art. 33 states that the commission charged with the evaluation of the management plan must verify the companies' choice of (a) the managed species, (b) the logging cycle, and (c) the calculations used to estimate the AAC (MINEF 2001).

In reality, companies are free to apply stricter management rules to species they do not necessarily harvest while ignoring some of the species making up the bulk of their annual production and profits. In other words, the legal requirement to include in the management plan at least 20 species that make up at least $75 \%$ of the total volume of the FMU, can be fulfilled without including some of the company's most harvested species, as shown by the management plan and production data for one of the concessions under management in Fig. 1. The managed species list for this concession consists of 29 species representing about $76 \%$ of the total inventoried volume, which is in line with the legal prescriptions. However, only 11 of these species are actually harvested, accounting for only about $14 \%$ of the 2006 production. Close to $85 \%$ of the 2006 annual production of this FMU was, therefore, realized by harvesting species not listed in the management plan while the AAC calculated in the management plan of this FMU is largely made up of species that are not harvested. 
Fig. 1. Managed species of a sample concession (29 species, $76 \%$ of the total inventoried volume) and actual harvested species (as percentage of the concession's total annual harvest in 2006).
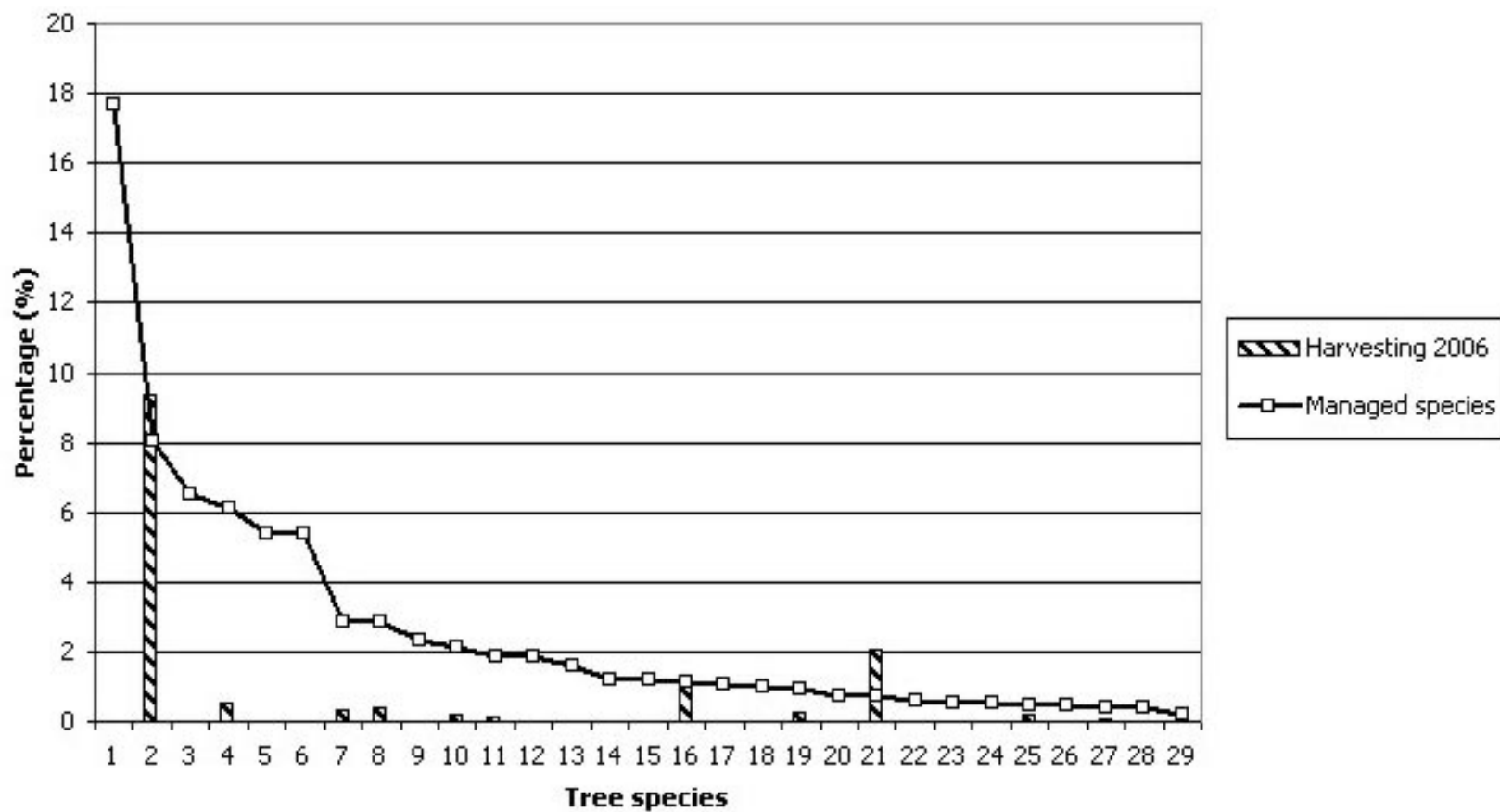

This obviously raises concerns about the meaning of the choices of key managed species made and about the value of the plan itself. The fact that companies are legally allowed to ignore some of their most harvested species in preparing and implementing their management plans casts a shadow not only on the application of the monitoring measures, for which the ministry is responsible as discussed later, but also on the reportedly positive ecological impacts that these plans could have for Cameroonian production forests. To assess the impacts of regulatory weaknesses and feeble controls, the next section will analyze detailed data obtained from 38 approved management plans and compare them with actual annual timber production.

\section{THE CONSEQUENCES OF A FLAWED REGULATION AND FEEBLE CONTROLS}

As most management plans have only been approved in 2004 and 2005, it has been difficult until now to evaluate the qualitative and, most notably, quantitative consequences of the implementation of the flawed decree $\mathrm{N}^{\circ} 0222$ into approved management plans. A qualitative assessment of 20 approved management plans was indeed carried out in 2006, and found that none of the plans entirely fulfilled the minimum legal prescriptions (Vandenhaute 2006). Evidences indicate that plans have then been approved though not fully legally compliant and control procedures appear deficient (Vandenhaute 2006), but the impacts on actual production have never been assessed.

There is enough data to make a preliminary quantitative assessment of the situation. As of 2007, 49 management plans had been approved. Only 38 plans have been reviewed for this study, for the following reasons: (a) some concessions with an approved plan were not operational in the years considered, (b) some plans are not yet fully implemented, and (c) some plans were not available for analysis. 
Some of the reviewed plans were accessed through the GTZ library and some were provided by logging companies. Given that this paper focuses on timber harvesting, data on social demands, land tenure, non-timber forest products, and wildlife protection were not analyzed, even though they are included in the plans. The most important set of data used is that derived from the management inventory results, which provide the population structures (volume and number of trees per diameter class) for all inventoried species and which are eventually used to calculate the AAC of the FMU.

In relation to production data, the analysis focused only on official data, i.e., data provided by the forestry ministry's Computerized Forest Information Management System (SIGIF). These data were available for each FMU and species harvested, two of the variables used in the analysis below.

By comparing management plans and production data from the SIGIF, it was possible to link each FMU's managed species, as per management plans, with their production, as per SIGIF.

The analysis was carried out following a two-step approach. First, the consequences of legal flaws on annual production were assessed by considering key species that are harvested but not part of the managed species. Second, impacts of the feeble controls carried out by the ministry on approved management plans were examined by considering how management parameters, such as the MCD, are modified to achieve better recovery and sustainability.

\section{Non "Managed Species" and Production}

In Cameroon, as well as in many other countries of the Congo Basin, not only is a handful of species harvested nationwide, but it is also common for logging companies to specialize in a subsetusually two or three-of those few species (RuisPerez et al. 2005). In 2006, on average $79 \%$ of each company's production was made up of the company's three most-harvested species, as recorded by SIGIF. Considering the 2006 production, results of our analysis show that $66 \%$ of the companies did not include at least one of their three most harvested species, according to SIGIF data, in the managed species list, as in the management plan, and that $26 \%$ of them did not even include their single-most-harvested species. In the latter case, the excluded most-harvested species accounted for an average of $44 \%$ of the annual production of all companies, with values ranging from a minimum of $20 \%$ to a maximum of $85 \%$ in the case of one company.

Allowing logging companies to legally exclude their most harvested species from the management plan means that management decisions are made on species not harvested and that stricter management rules are not applied to the largest part of the companies' production. Consequently, all policies based on management plans and adopted to improve the sustainable management of the Cameroonian forests are, at best, weakened.

In 2006, these non-managed species, as in the management plans, represented about $266000 \mathrm{~m}^{3}$ (23\% of the annual harvest in the sampled concessions), according to SIGIF data, whereas the 15 most-harvested species accounted for about $88 \%$ of the total non-managed production (Fig. 2), clearly indicating that species are not randomly excluded by companies from their management plans. Rather, species are excluded because they have a high commercial value and managing them would mean the company must apply the precautionary principle, thus likely increasing their MCDs and reducing the annual production.

Given the emphasis of all adopted forest policies on sustainable management (to be reached through the implementation of management plans), it is remarkable that species classified as endangered by the IUCN red list (IUCN 2007)—such as assamela (Pericopsis elata) - or vulnerable, usually because of overexploitation as a timber-such as azobé (Lophira alata), kossipo (Entandrophragma candollei), moabi (Baillonella toxisperma), and sapelli (Entandrophragma cylindricum) - can legally be excluded from the list of managed species.

Yet, the fact that these species are not included in the management plans does not mean, in itself, that they are unsustainably harvested. Therefore, it is necessary to assess whether non-managed species are nonetheless being harvested in line with the precautionary safeguards rhetorically supported by the logging companies and the ministry.

Unfortunately, that is a hard task because companies are not required by law to provide detailed data on the species not considered in the management plan. Fundamental parameters such as the reconstitution 
Fig. 2. Non-managed production in concessions with approved management plans, 2006 (15 mostharvested species) and percentage over total production of each species.

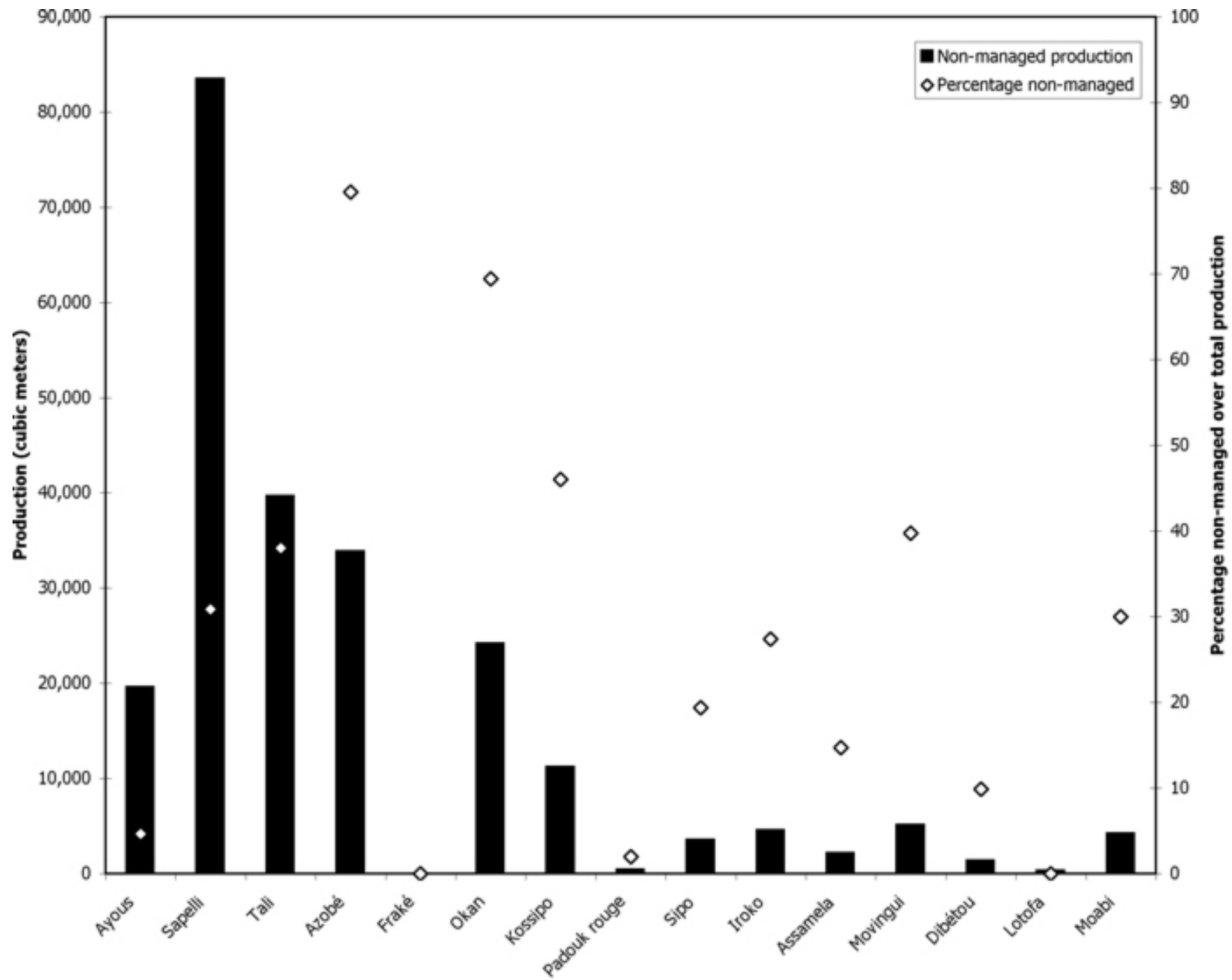

rate could only be calculated for the plans that provide these data. Results are remarkable, however, and show that species excluded from the management plans are actually legally harvested with MCDs set at values far below accepted precautionary safeguards (to allow $50 \%$ recovery). The average recovery value for these harvested but not managed species was $13 \%$. Some key species presented values as low as $5 \%$, meaning that only $5 \%$ of the number of trees harvested for that given valuable species, in the considered FMU, will be found during the subsequent harvesting cycle, well below the suggested $50 \%$ rate. Those low rates are a sign of overharvesting but they also clearly undermine the willingness of any logging company to bid for that concession in the future, with potential consequent economic losses for the State. Indeed, if minimal sustainable safeguards were applied, excluded species with the abovementioned low recovery rates would be included in the 
management plan and their MCDs increased to achieve better recovery rates.

Before proceeding further, it is worth mentioning that, although in line with Decree $\mathrm{N}^{\circ}$ 0222, the exclusion of key species from management plans could be avoided if the controls that the ministry must carry out before approving the plan were properly done. As shown above, controls never detected the problem and plans were approved. It is reasonable then to ask whether better controls have been carried out on the species considered in the management plan.

\section{Managed Species and Production}

We now turn our attention to situations where a management plan is implemented but there exists the risk that sustainable management is not. That is because, if the overall approval procedure has been weakly enforced-as shown by Vandenhaute (2006) and our previous analysis - the technical prescriptions adopted for the managed species may also prove not to be aligned with the precautionary approach.

Indeed, our results show that $64 \%$ of companies that did include their single-most-used species in their managed species list did not increase their MCDs, implying that practices in place before approval of the management plan were already sustainable. About $45 \%$ of the 2006 annual production is made by managed species whose MCDs have not been increased, as shown in Fig. 3 for the 15 mostharvested species (Fig. 3 does not consider nonmanaged production shown in Fig. 2).

If sustainable management rules were effectively applied, one would expect MCDs to be higher for a significant number of FMUs and species, and that timber production in managed FMUs would be lower as assumed by the 2006 economic audit of the Cameroonian forestry sector (Republic of Cameroon 2006). The audit even proposed a proportional reduction of annual area taxes to compensate logging companies for the costs incurred in implementing sustainable management, implying that lower harvested volumes were to be generally expected because of increased MCDs.

The introduction of management plans has had some impacts on the harvesting of ayous (Triplochyton scleroxylon) and sapelli, the two historically most-harvested species. Data show that about 34\% and 30\% respectively of the 2006 production of ayous and sapelli, respectively, were obtained in concessions where the MCD was increased (Fig. 3).

However, about $66 \%$ and $70 \%$ of the 2006 production of the same two species came from managed FMUs where their MCDs were not increased. Examples of other very valuable species, coupled with previous findings about species not included in management plans, are striking. For instance, $15 \%$ and $30 \%$ respectively of the total 2006 production of assamela and moabi was obtained from FMUs where these species are not in the managed species list (Fig. 2), while the remaining $85 \%$ and $70 \%$, respectively, were harvested without increasing the MCDs (Fig. 3). We could say that the implementation of management plans in Cameroon, and the sustained production they imply, did not change a single harvesting parameter for assamela and moabi. Ironically, the above data seem to suggest that sustainable management was already implemented in Cameroon before management plans were introduced.

In reality, the latter statement is proved wrong by the example of the first FSC-certified company in Cameroon, detailed in the next section, which clearly indicates that sustained production was not in place before management plans were introduced and that there is a significant risk that they are still not in place even with an approved and implemented management plan.

\section{CERTIFICATION AND SUSTAINABLE MANAGEMENT}

The first FSC certificate in Cameroon was granted to a logging company in December 2005, and others followed in 2007 and 2008. As of mid-2008, the total area of the seven certified FMUs in Cameroon was about 560000 ha, with several other companies well advanced in the process. Certification goes well beyond the legal technical prescriptions required for management plans, but we will only consider issues directly related to management plans as a complement to the previous findings and further illustration of the legal weaknesses persisting in the sustainable management of the Cameroonian forests. 
Fig. 3. Managed production of each species with no increase in MCD in concessions with approved management plans, 2006 (15 most-harvested species).

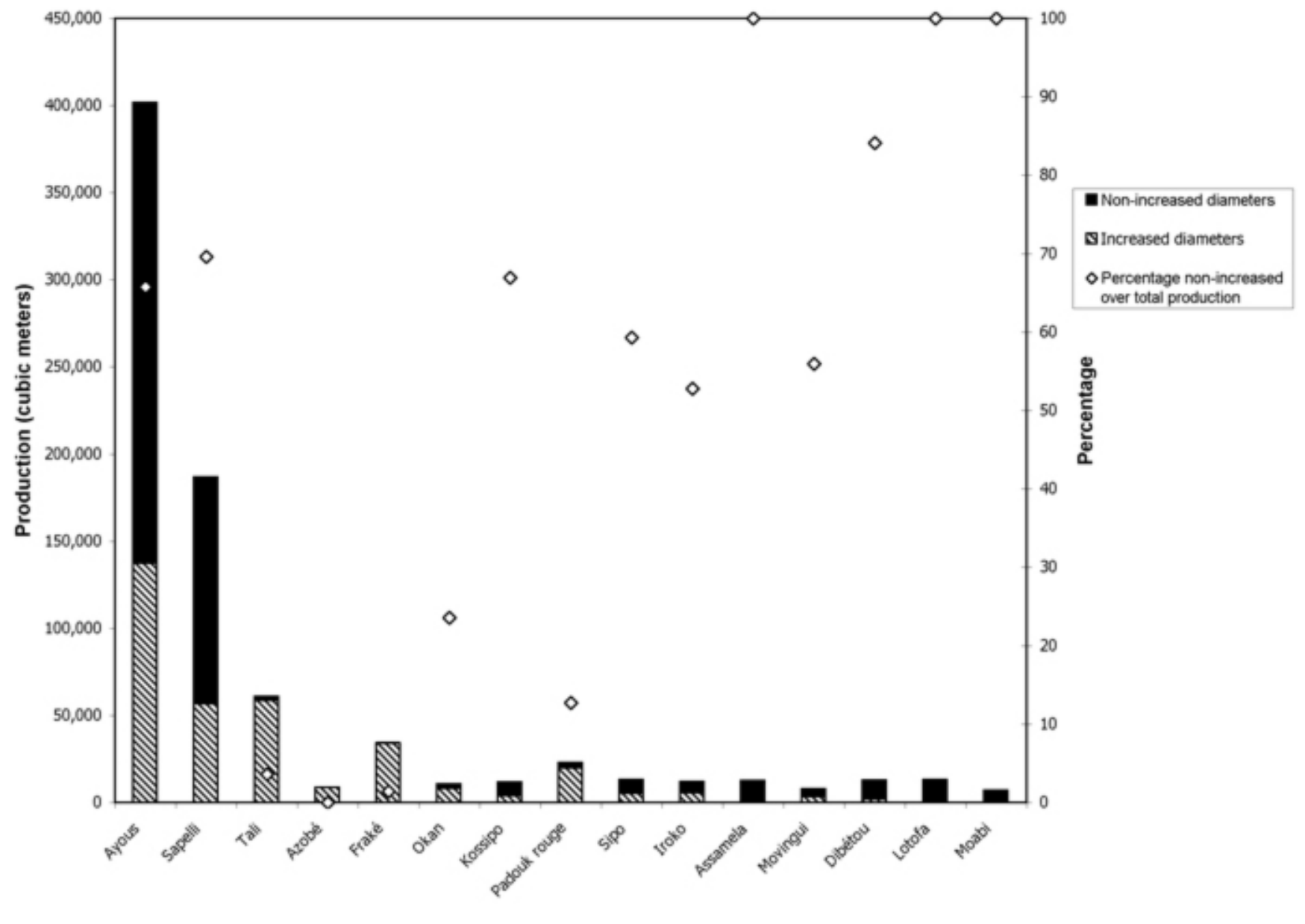

The company seeking certification in 2005 had an approved management plan but before certification could be granted, the certification body imposed an increase in MCD for some species because "it appeared that, for [those] species (particularly the company's most logged one) they were not compatible with a sustained production" (Bureau Veritas Certification 2006:24).

However, were the company to respect the arbitrarily imposed minimum reconstitution rate of at least $50 \%$ on its single-most-harvested species, the MCD would have had to be increased from 60 $\mathrm{cm}$ to $90 \mathrm{~cm}$, resulting in a "marginal production not compatible with the profitability of the company" (Bureau Veritas Certification 2006:30). Thus, the solution suggested by the certifying body and accepted by the company was to adopt an increased MCD $(80 \mathrm{~cm})$. This parameter still does not allow a reconstitution rate of $50 \%$ but it at least allows for a larger number of trees to remain standing after logging, thus increasing the likelihood of future regeneration.

This example illustrates well the type of trade-offs between economic and ecological sustainability faced by companies wanting to engage in sustainable management in Cameroon. It also shows that solutions on management issues can be proposed, evaluated, negotiated, and eventually 
accepted by the logging company and the certification body.

Although certification remains a voluntary process, with principles and criteria to be respected beyond the legal framework, one of its core objectives, i.e., sustainable forest management, is deeply embedded in the Cameroonian legal environmental framework. We argue the appropriate setting of fundamental silvicultural parameters, such as the MCD, must be a governmental concern well before it becomes a certifying body's one.

In fact, even after the suggestions by the certification body, the ministry failed to internalize the negotiated solution proposed by the certifying body and accepted by the logging company. So far, no modifications in the prescriptions of the management plan in place have been requested by the ministry. This leaves the management plan, the only official and legal document on which to base the sustainable use of the concession, with a reportedly unsustainable MCD for the single-mostharvested species.

Paradoxically, if a control of legality (such as those envisaged by the forthcoming EU-Cameroon VPA negotiations) was carried out by ministry officials or by independent observers on the certified FMU, the cutting of the single-most-used species at a 60$\mathrm{cm}$ MCD would be perfectly legal, albeit contrary to the precautionary safeguards voluntarily agreed by the company and adhered to by the ministry.

Thus, although the certification process helps logging companies develop improved management rules in Cameroon, the ministry remains a silent actor on matters related to sustainable forest management, with a risk that the most progressive logging companies incur an inequitable treatment, being forced to adopt stricter safeguards that other companies, not engaged in certification, will not need to adopt, while competing for the same handful of timber species that can legally be harvested unsustainably.

We agree that certification should be a step ahead the common benchmark level, possibly the legal one, but when the latter is proven to allow unsustainable harvesting, it must be improved to oblige all logging companies to adopt at least recognized minimum precautionary safeguards without waiting for logging companies to engage voluntarily in the certification process. In fact, certification in Cameroon can still be used to differentiate between companies that adopt those minimum safeguards and companies who can legally choose not to.

\section{CONCLUSION}

In 2000, when only few management plans had been prepared and none approved, an assessment made for the ministry concluded that their quality was dubious and "if Cameroon were not to implement sustainable management, in twenty years time it would have only had to manage degraded forests emptied of all valuable species" (Durrieu de Madron and Ngaha 2000:95).

In 2001, a decree regulating the preparation of management plans was issued but it did not really consider this warning. We have shown how some of the existing management plans comply with most legal prescriptions but still neglect the adoption of minimum precautionary safeguards.

It is fair to assume that at least since 2005 (when the first company operating in Cameroon received its FSC certificate and had to increase the MCDs to alleviate concerns about sustainability), the ministry has been aware of the inconsistencies in the legal framework that have been discussed in this paper. However, the ministry has neither modified the 2001 decree nor asked a single company to modify its management plan, including those companies that received other FSC certificates and were again asked by the certifying bodies to increase several of their MCDs.

Overall, the reasons behind the persistence of the flawed legal framework could be ascribed to a lack of political will to back the commitments made, nationally and internationally, for a more sustainable forest management. However, a focused political will oriented toward improved management of the forests could be difficult to maintain when there are very different, and sometimes contrasting, forces that come into play and shape the ministry's list of priorities, with the result that changes are very difficult to implement.

On the one hand, asking companies to decrease the harvested volume of valuable timber would engender a decrease in revenue collection, at least 
until less-harvested species reach their expected market potential. This would be a difficult policy change to adopt for any ministry in a country constantly under pressure to increase revenues.

On the other hand, it would be at least as difficult to change a regulation whose flaws have been exploited for years by many logging companies, considering their powerful lobbying capacity.

In 2006, about $23 \%$ of the total production recorded in FMUs considered for this paper was made up of very valuable species legally excluded from management plans, i.e., not managed. Moreover, about $45 \%$ of the 2006 production was made up of species considered in the plans but whose fundamental technical parameters (MCDs or reconstitution rates) were left unchanged. This results in about 68\% of the 2006 supposedly sustainable production not incurring any management prescription. In the worst cases, e.g, for assamela and moabi, $100 \%$ of the harvest was produced as if no management rules were in place.

Through a comprehensive analysis, we confirm that although forest management is slowly improving in Cameroon, especially thanks to the efforts made by some motivated logging companies, it is still not perceived as a top priority for most of them, and the increasing number of approved management plans does not equate with sustainable forest management as implied by many national and international sources.

The law requires FMPs to be revised every 5 years, to take stock of improved knowledge and data. The ministry should not wait, however, for logging companies to push for those modifications in the coming years. It must become the leading actor in the improved management of Cameroonian production forests. Official and continuous quality control of approved management plans should be effectively implemented if sound changes and improvements are to be achieved.

We do not contend that basic silvicultural parameters, such as the MCDs, must be fixed by law or that all species must have reconstitutionrates greater than $50 \%$. That would be an arbitrary and, in several cases, probably wrong decision. We do argue, however, that logging companies must (a) include all their most-harvested species in the list of managed species and (b) present a sound ecological and economic evaluation of the reasons why logging should be allowed without stricter management prescriptions for some species. Negotiation of trade-offs between ecological constraints and economic viability must be initiated by the ministry and this can be accepted by motivated logging companies, as showed by the example of the first FSC-certified company in the country.

We emphasize that it is the role of the ministry to assess companies' basic management parameters and whether to grant permission to log. Ideally, this fundamental control should take place before new management plans are approved and as soon as possible for those already approved. However, if the ministry remains a silent actor, sustainable management will not be implemented on a large scale in Cameroon and companies voluntarily applying stricter management rules will suffer inequitable treatment because competitors will harvest their FMUs legally but unsustainably.

Were the present status quo maintained, it is possible that even the most progressive companies in Cameroon, some of which adhere to the recently released industry vision for the forest sector in 2015 (Balfour Beatty Group et al. 2008), will halt their efforts toward improved management and certification, opting for less-demanding legal compliance certificates, such as the one delivered after the signature of the VPA with the EU. Their production will be legally compliant, in Cameroon as well as in Europe, but even the most basic and widely recognized minimum management safeguards will not be applied.

Responses to this article can be read online at:

http://www.ecologyandsociety.org/voll3/iss2/art36/responses/

\section{Acknowledgments:}

We wish to thank Marc Vandenhaute, Eric Forni, Luc Durrieu de Madron, Didier Bastin, François Hiol Hiol, and Sebastien Delion for their availability to discuss some of the issues covered in this paper. We also wish to thank two anonymous reviewers for the useful comments they provided on a preliminary version of this article. The views expressed in this paper are those of the authors and do not necessarily reflect the views of the organizations with whom they are associated. 


\section{LITERATURE CITED}

Balfour Beatty Group, DLH, Rougier, InterAfrican Forest Industries Association, John Bitar and Co., Precious Woods, Reef Hout, Likouala Timber, and Timbmet Group. 2008. The future of tropical forestry: a progressive industry vision for the forest sector. Global Legislators Organization for a Balanced Environment (GLOBE) Brasilia G8+5 Legislators Forum. Brasilia, Brasil.

Bureau Veritas Certification. 2006. Rapport public de certification-Certification de gestion forestière - Unité forestière d'aménagement $n$. 09021 WIJMA Douala (GWZ). Bureau Veritas Certification, Paris, France.

Congo Basin Forests Partnership (CBFP). 2006. Les forêts du Bassin du Congo-État des forêts 2006. CBFP, Kinshasa, Democratic Republic of Congo.

Commission des Forêts d'Afrique Centrale (COMIFAC). 2004. Plan de convergence pour la conservation et la gestion durable des écosystèmes forestiers d'Afrique Centrale. COMIFAC, Yaoundé, Cameroon.

Durrieu de Madron, L., A. Karsenty, E. Loffeier, and J.-M. Pierre. 1998. Le projet d'aménagement pilote intégré de Dimako (Cameroun) (1992-1996). Document Forafri N. 7. CIRAD-Forêt, Montpellier, France.

Durrieu de Madron, L., and J. Ngaha. 2000. Revue technique des concessions forestieres. République du Cameroun - Comité technique de suivi des programmes économiques. Yaoundé, Cameroon.

European Commission. 2007. Voluntary partnership agreements. FLEGT Briefing Notes Number 06 Forest Law Enforcement, Governance and Trade. European Commission, Brussels, Belgium.

Fargeot, C., E. Forni, and R. Nasi. 2004. Quelques outils de l'aménagement forestier dans le Bassin du Congo. Bois et Forêts des Tropiques 281(3):19-34.

Forni, E., and N. Mbarga. 1998. Applicabilité des plans d'aménagement: comment réconcilier aménagiste et exploitant; exemples du Cameroun. Séminaire Forafri. CIRAD, Libreville, Gabon.
German Development Cooperation (GTZ) and Ministére des Forêts et de la Faune (MINFOF). 2006. Programme sectoriel Forêts et Environnement (PSFE) - Suivi d'impact de la gestion forestière au Cameroun - situation de référence des UTO du Sudouest et de l'Est. GTZ - Natural Resources Sustainable Management Program) and MINFOF, Yaoundé, Cameroon.

Hédin, L. 1930. Étude sur la forêt et les bois du Cameroun sous mandat française. Librairie Larose, Paris, France.

Inter-African Forest Industries Association (IFIA). 2006. IFIA newsletter: is forest management improving in the tropics? [online] URL: http://www.ifiasite.com/.

International Tropical Timber Organisation (ITTO). 2006. Status of tropical forest management 2005. ITTO, Kyoto, Japan.

IUCN. 2007. 2007 IUCN red list of threatened species. [online] URL: http://www.iucnredlist.org/

Jonkers, W. B. J., and B. Foahom. 2004. Sustainable management of rain forest in Cameroon: the Tropenbos approach. TROPENBOS International, Wageningen, The Netherlands.

Karsenty, A., and S. Gourlet-Fleury. 2006. Assessing sustainability of logging practices in the Congo Basin's managed forests: the issue of commercial species recovery. Ecology and Society 11(1): 26. [online] URL: http://www.ecologyandso ciety.org/vol11/iss1/art26/.

Letouzey, R. 1957. La forêt à Lophira alata de la zone littorale Camerounaise. Bois et Forêt des Tropiques 53:9-20.

Luckert, M. K., and T. Williamson. 2005. Should sustained yield be part of sustainable forest management? Canadian Journal of Forest Research 35:356-364.

Meniaud, J. 1948. État actuel de la production et du commerce des bois exploités dans nos forêts africaines. Bois et Forêt des Tropiques 6:175-183.

Ministry of Environment and Forests (MINEF). 1998a. Directives nationales pour l'aménagement durable des forêts naturelles du Cameroun. ONADEF - ITTO, Yaoundé, Cameroon. 
Ministry of Environment and Forests (MINEF). 1998b. Guide d'élaboration des plans d'aménagement des forêts de production du domaine forestier permanent de la République du Cameroun. Ministry of Environment and Forests, Yaoundé, Cameroon.

Ministry of Environment and Forests (MINEF). 2001. Arrêté $N^{o}$ 0222/A/MINEF du 25 mai 2001 portant procédures d'élaboration, d'approbation, de suivi et de contrôle de la mise en oeuvre des plans d'aménagement des forêts de production $d u$ domaine forestier permanente. Ministry of Environment and Forests, Yaoundé, Cameroon.

Ministry of Environment and Forests (MINEF). 2004. Planification de l'attribution des titres d'exploitation forestière. Ministry of Environment and Forests, Yaoundé, Cameroon.

Ministry of Forests and Fauna (MINFOF). 2007. Bref aperçu du secteur forestier camerounaise. MINFOF, Yaoundé, Cameroon.

Ministry of Forests and Fauna (MINFOF) and Food and Agricultural Organization (FAO). 2005. Évaluation des ressources forestières nationales du Cameroun, 2003-2004. MINFOF and FAO, Yaoundé, Cameroon.

Ntep, N. 2000. Directives nationales et schéma directeur d'aménagement. Séminaire atelier: Elaboration du Plan d'Aménagement du Site du Programme Tropenbos Cameroun. The TropenbosCameroon Programme, Kribi, Cameroon.

Repetto, R. 1988. The forest for the trees? Government policies and the misuse of forest resources. World Resource Institute, Washington, D.C., USA.

Republic of Cameroon. 1994. Loi $N^{\circ} 94 / 01$ du 20 janvier 1994 portant régime des forêts, de la faune et de la pêche. Republic of Cameroon, Yaoundé, Cameroon.

Republic of Cameroon. 1995. Décret $N^{\circ}$ 95-53-PM du 23 août 1995 fixant les modalités d'application $d u$ régime des forêts. Republic of Cameroon, Yaoundé, Cameroon.

Republic of Cameroon. 2006. Audit économique et financier du secteurforestier au Cameroun-Draft $n^{\circ} 1$ - Août 2006. Republic of Cameroon, Yaoundé, Cameroon.
Ruis-Perez, M., D. Ezzine de Blas, R. Nasi, J. A. Sayer, M. Sassen, C.Angoué, N. Gami, O. Ndoye, G. Ngono, J.-C. Nguinguiri, D. Nzala, B. Toirambe, and Y. Yalibanda. 2005. Logging in the Congo Basin: a multi-country characterization of timber companies. Forest Ecology and Management 214(1-3):221-236.

Schanz, M. 1914. Colonies Allemandes-le régime forestier dans les colonies allemandes. Pages 5-17 in Bibliothéque coloniale internationale. Le régime forestier aux colonies. Eleventh edition, volume III.

Vandenhaute, M. 2006. Étude comparative de 20 plans d'aménagement approuvés au Cameroun. German Technical Cooperation, Yaoundé, Cameroon.

Wijma Douala S.A.R.L. 2004. Plan d'aAménagement durable UFA 09-021. Douala, Cameroun.

Wunder, S. 2003. Oil wealth and the fate of the forest. Routledge, London, UK and New York, New York, USA. 